\title{
Corporate social responsibility in Pakistan economy
}

\author{
Aon Waqas Awan ${ }^{1}$, Dr. Yasir Kamal', Dr. Muhammad Rafique ${ }^{3}$, \\ Shahbaz Khan $^{4}$
}

\begin{abstract}
Research Question/Issue: This research aims to comprehend the level of corporate social responsibility in Pakistan. The need of the hour is to assess and identify the coverage of the corporations toward its social responsibility. How much each of the elements has its contributions in achieving that level and how we can overcome all of these deficiencies?
\end{abstract}

Research Findings/Insights: By archival data from different companies in Pakistan with a sample of 110 to 120 companies. We find that Pakistan has a moderate level of corporate social responsibility (a numeric value). And "social accountability and social investment" was the main variable contributing in scoring that level. We identify the most weakest and stronger sub variables that have a negative or positive impact on overall CSR in Pakistan. Society, company as well as government ought to effort jointly additional intimately for getting better creature answerability.

Theoretical/Academic Implications: This research provides an empirical hold for the all the companies in Pakistan to improve their index of social accountability, ethics, human resource, environmental protection, corporate governance and finally corporate social responsibility.

Practitioner/Policy Implications: This research offers imminent to executive level managers and Government concerned with maximizing of the level of corporate social responsibility in Pakistan. This gives a dimension or guide of company's accountability at country or community stage.

Keywords: Corporate social responsibility, Organizational strategic planning systems, Corporate governance and economic responsibility, Ethics and human resources, Environment protection and sustainability.

1 Research Associate, Institute of Management Sciences, Peshawar, Pakistan. Email:aon_waqas@yahoo.com, Phone No.+923336820133

2 Assistant Professor, Institute of Management Sciences, Peshawar, Pakistan. Email: yasir.kamal@imsciences.edu.pk, Phone No.+923335550855

3 Assistant Professor, Institute of Management Sciences, Peshawar, Pakistan. Email: muhammad.rafiq@imsciences.edu.pk, Phone No.+923339155096

4 MS Student, SZABIST, Islamabad, Pakistan. Email Id:shahbaz.khans@yahoo.com, Phone No. +923347931215 


\section{Introduction}

In this competitive century, businesses are more interested toward all elements of corporate social responsibility. They are conscious about their human rights, ethics, socially responsible and many other factors. Simultaneously, corporations are feeling a lot of pressure from public and from their regulatory authorities. As it also been found by the researcher that financial performance of the firms are dependent on their social responsibility acts. However, beyond the financial advantages there are many other advantages due to which firms are involved in social responsibilities. These advantages includes building the loyal customers, risk minimized due to competition companies perception improved, building culture about the organization that firm is doing the right things, following steps to execute matters linked to labour standards and safety and health strategies, and so on. Companies are using corporate social responsibility approaches to come first in the war that is for talent (Bhattacharya et al., 2008). A corporate social responsibility policy effects in a triple hub for a company: people, profit and planet. There are different reasons accountable of sharp increase in companies that are accepting social responsibility. First of all, customers are very much mature they have strong feelings for society, so there preferences go to that product that also includes these feelings. Secondly, due to globalization confront in favor of companies regarding its varying standards, tariffs, administration policies, moral matters, labor exploitation, and ecological limits, along with many others. Both of these concerns are expensive in favor of the companies. Therefore companies exercise these strategies that are socially responsible. Many companies use corporate social responsibilities methodologies like tactical method for increasing community hold and occurrence internationally; also help the companies to maintain spirited benefit by the communal attachment for presenting unconscious stage for publicity (Fry et al., 1982).

Additionally, the presence of upward tendency of private organizations for grasping company's liable in support of businesses dealings (Roux, 2007). Administration policies somehow also need companies for grasping usual moral guidance due to which their workers feel pride plus loyalty. Also, companies more and more like their policies, practices, actions and behaviors to noticeable by different signs of corporate social responsibility. Therefore, companies are place beneath gigantic stress toward stay away from damage regarding the wider communal wellbeing, as well as surroundings and the people.

\section{Literature Review}

A lot of work has been done in the field of corporate social responsibility worldwide. Due to broad nature of data this paper will only focus on the key 
issues. As for as CSR is concerned, it gain more attention in 1970's. Many researchers were of suggested that corporate social responsibilities was wastage of money and time for corporation. However others were taken keen interest on CSR.

In 1970 Milton Friedman along with some further quarrel to corporate social responsibilities are unsuitable for entrepreneurship as well as important reason with scenery with the company. That are merely citizens to contain care for CSR; companies contain thumbs down compulsions for civilization. Company has only concern to create the majority of profits. Adversary of CSR have rationally quarreled the opposite, highlighting the financial expenses of subsequent like 'mistaken good value' because corporate social responsibility. As, social responsibilities expenditure of Nike is more than $\$ 10$ million yearly, only intended in favor of corporate social responsibility. Though in 1970 (Friedman) labeled corporate social responsibility as a 'dissident doctrine', the majority of the business cluster of people has cuddled it. Actually, a proprietor worth improved due to moral trade manners. In summary, Corporate Social Responsibility is winning condition for both companies and the community.

Authors also explained the reason that why firms involved in CSR activities? Likewise, Osorio (2006) states with the intention of different authors "Earnings seeking provide the social reasons." Osorio also put in with the purpose of performing no matter which to reduce their base line, corporations creates the globe inferior - and there's not amazing responsible in that. Theses argue will carry on concerning CSR since many corporations' leaders sense to the corporations are poorly operational by follow wider communal activities, comment so as to corporations contain none of self-governing validity for different occupations. In short condemnation beside corporate social responsibility is that a lot of international companies like McDonalds, BAT, gasoline huge BP plus almost immediately taking corporate social responsibility agenda for digression a community as of moral queries lifted through the center company processes, for example unwanted physical condition belongings of cigarette (McKibben, 2006).

The main view in resistance to the completion of corporate social responsibility protect that neo-liberalism are fence in the direction of creature liberty in addition to appearance for cultural with economic conditions for rising states out pending within labour misuse through international corporations. Likewise, the most well known and documented CSR activity in Pakistan relates to child labour: for instance, Hussain-Khaliq (2004) confirmed cases of the positive impact of CSR acceptance in the struggle to vanish child labour that worked in sports goods industry in the city of Sialkot. 
There are many studies relevant to developing countries which show the importance of CSR at country level. The study done by Aishah et al. (2011) has measured CSR in Malaysia, they find that the companies having CSR activities are the leading one and score higher than others. Same study was done by Asghar and Richard (2009), this study analyzes and compare CSR in Pakistan and Bangladesh. According to their results Multi National Corporations in both countries have CSR at good level as compared to others.

In Pakistan Corporate Social Responsibility is slowly making inroads in the multinational and private sectors (Khan and Nomani 2002). A lot of companies argue to be involved in CSR activities, mainly philanthropy and charitable giving (Lund-Thomsen et al. 2006), for a different reasons. The PCP (Pakistan Centre for Philanthropy) published research on the charitable activities of 568 unlisted (private) and listed companies. In this study a combination of interviews and a review of annual reports were used to reach at its conclusions, enlightening 'that $64 \%$ of the PLCs reports have several social development initiatives'. Although companies 'give mostly for faith-based reasons and humanitarian, 'tax benefits, improved public relations and marketing advantages are also observed as reasons albeit to a lesser extent (PCP 2005: v). The study, however, used 'only in-kind donations and cash' to explain corporate philanthropy, off-putting its usefulness as a pointer of CSR in the background of the present study.

Different researchers have used different variable for their studies. Social investment is the main factor of for CSR because it is very broad means for investor toward considering corporate social responsibility information's in their investments decisions. On the other hand, some researchers have strong argument in opposition to social investment fund, saying they do not perform either better or worse than other fund (Noergaard et al. 2011). Corporate governance (CG) importance cannot be ignored, corporate social responsibility practice revolve around requirement of better corporate governance in the Asia Pacific region. CG is the foundations upon which better CSR practice is build, however better CG has a lot toward learning from key principle of better CSR (Richard, 2007). Importance of ethics and behavior of firm toward social responsibility cannot be ignored. As David et al. (2005) explained that a growing trend on the CSR and firm's ethics and behavior toward it has positive or negative effects on the society. Variables used in study of CSR in Pakistan and Bangladesh by Naeem and Richard (2009) were labour right, Human right, Anti-corruption, and environmental protection.

As for as data collection and methodology is concerned, different studies have used different data collection tools and methodology. In the study of 
Aishah et al. (2011) the data was collected from all listed companies of Malaysia through questionnaire method. A sample of 333 companies was selected from six industries. Likewise Asghar and Richard (2009) in their study use simple random sampling and selected 100 firms from Bangladesh and Pakistan each. But all these firms were listed firms. A questionnaire method was used for collecting data. According to the results Multi National Corporations in both countries have CSR at good level as compared to others.

As for as Pakistan is concerned, there is limited work on CSR but none of the researchers has described that in Pakistan CSR is at which stage. No one has described it numeric form that in Pakistan CSR is $20 \%$ or $80 \%$. This gap will be filled by this article by using the formula use by Kanji and Chopra (2007). Kanji and Chopra (2009) measure CSR in global economy by using survey methodology (questionnaire), by simple random sampling they selected 400 firm throughout the globe and use AMOS-SPSS for the analysis. They described each and every element importance in calculating overall CSR. By using that formula and methodology our paper will calculate overall CSR score in Pakistan and also the importance of the each factor.

Nevertheless, despite rising CSR activity in Pakistan, the literature appears to be determined around economic development, issues concerning NGOs active and philanthropy in the country. There exists, therefore, a gap in the literature about many issues of socially responsible corporate action in Pakistan.

\section{Corporate Social Responsibility Model (CSRM)}

All through the text, it is more often than not decided that CSR is very important for business continued existence and achievement (Trapp, 2009). The essential rules of fair business comprise light prices (low floor prices), straight trade (no middlemen if achievable), fair labour circumstances (with a total ban on child labour), and environmental sustainability. Though, it is very significant to be acquainted with that at what level company is involved in CSR activities. So the requirement in favor of a structure or skeleton in the direction of evaluating the process of Corporate Social Responsibility connected toward organization. Previously no efforts made into clarification of numerous fundamental societal liability variables like economic responsibility, and communal speculation. Also, the difficulty was that how will the importance of these variable can be linked to real life. This CSR study gives a device that will create a communication for the system about corporate social responsibility. This examination will give identification, categorization plus 
recognition and after that reply in the direction of Corporate Social Responsibility. An extremely many-sided fact such as CSR is a major challenge in front of Pakistani and international corporations. How on the way to agreement by means of CSR connected with working with ruler authority wants multi punitive method in favor of dimension, conceptualization in addition to examination.

In this paper, for that reason, present a new CSR gauge depends on holistic and system modeling approaches. It builds a latent variable structural equation model using systems mechanism (see Figure 1) to determine CSR within certain limits of the OSPS. This study splits CSR catalog into SASI, EPS, CGER and HER.

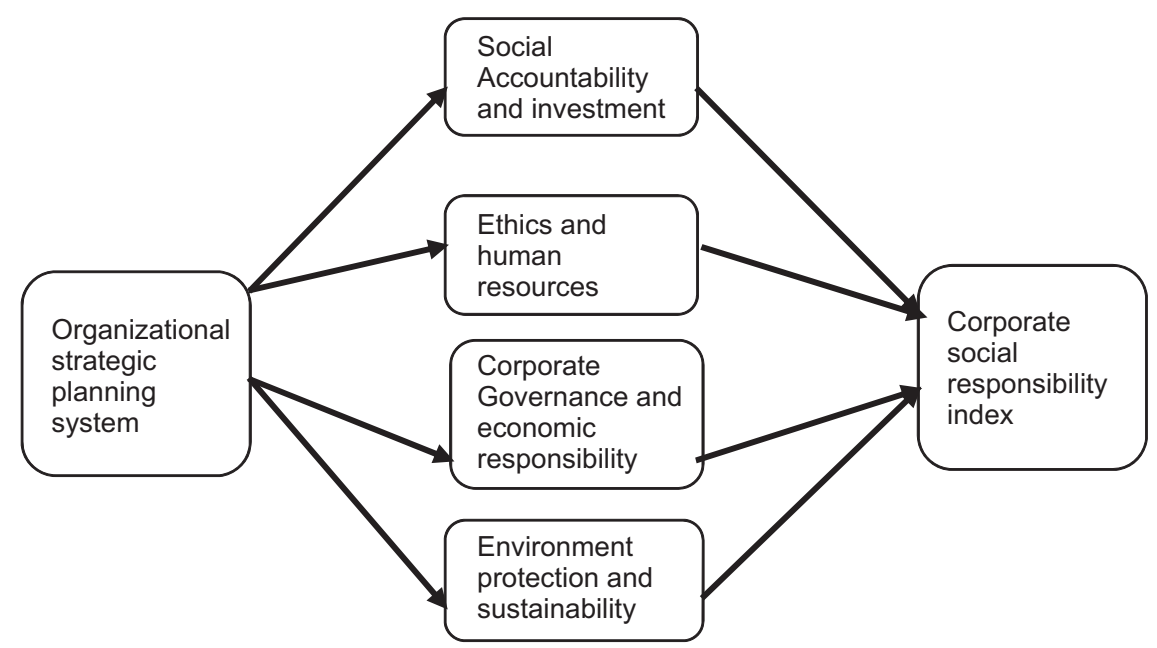

Figure 1: Corporate Social responsibility model (CSRM).

\section{Methodology}

In the CSRM the OSPS (organizational strategic planning systems) provide the foundation for GER, EPS, and SASI along with HER. Manner in which they were supported as well as developed would decide level for CSR; therefore that was confronts for national with multinational corporations toward efficiently handle relationship between CSR constituents.

During the following cases underlying variables structural's models will be exercised for signifying the cause effect relationship between underlying variable. On behalf of requirement of CSR evaluations that was essential for organization in the direction of distributing significant result in term of cause effect relationship along with structure approaches; namely to say with the purpose of analyses will be model based. SEM (Structural's equations model- 
ing) gives mean that be able to test relationships. Toward approximating power of cause effects or connection, this is essential on behalf of every underlying variable for operationalizing that is they are measurable and when these are measurable we say them manifest variables. Actually, by using measurement instruments the manifest variables are measured, like questionnaire; as well, these act like indicator of underlying variables.

Structural equation models usually have several assumption, that are non dependence of variable, random sample respondent, linear of every relationship, multivariate normal distributions, non kurtosis's with non skew ness's, suitable data's measurements on interval's or ratio's scales and samples sizes among hundred to four hundred.

Significance of gathering those forms lying on estimations method that is utilized. A number of estimations methods might regulate in favor of infringement form the few of all assumption. CSR measurement software's (CSRMS) fundamentally use the PLS methods for instantaneous estimations of weight for constructing the Corporate social responsibility systems. For maximizing the fitness of the model's, we calculate these weights and so the ability to clarify CSR as the final endogenous variable.

The approach applied for CSR measurement reflects two approaches:

1. Its general aims, objective and purposes

2. Value to cost consideration for rising along with working systems

Alignment and integration among different general subsystem denotes with the intention of corporate social responsibility measure have to deployed as well as compatible within logical ways inside the business. Here we will consider the first approach that is their general objective and purpose. The general approach for corporate social responsibility measurement includes the following steps:

1. Accepting the CSR model is like the framework for measuring CSR beside a set of entrenched criteria that communicate to the OSPS (organizational strategic planning systems).

2. Identifying the main or key CSR contributors from those we can collect feedback.

3. Using well established questionnaires that cover each and every of area of the CSR model so that we will conduct assessment exercise. 
4. After the data is collected we will introduce it to software.

5. In order to get the systemic system's scores and parameters, the correspondent program files running is necessary. For this purpose AMOSSPSS is used (highlighting cause-effect relationship)

6. Analyze those scores in favor of every measure, generally Corporate Social Responsibility indices furthermore also relationship of corporate social responsibility with other variables.

7. Design and implement the improvement strategies and also monitor it with its result.

8. Doing again the procedure as of the $3^{\text {rd }}$ steps.

\subsection{Corporate social responsibility indices}

For determining the index of corporate social responsibilities and also indices of its all dimension, the formula used is as follows: (Kanji and Chopra, 2007, 2009)

$$
\text { CSRI } \frac{\Sigma W_{i X i}-\Sigma W_{i}}{(\mathrm{~N}-1)} \frac{1}{\Sigma} \bar{W}_{\mathrm{i}}-100 \rightarrow 1
$$

where $w i=$ outer coefficients; $x i=$ manifest variables; and $\mathrm{N}=$ no. of point on scale.

The range of the index is between 0 to 100 . Zero shows that there is complete absence of CSR; value nearer to 100 shows higher social responsibility. And we can measure it through the above formula.

\subsection{Sample size and data collection}

Collection of data through the questionnaire is the main instrument to determine CSR. As all CSR dimension cannot be straight measured because of there multifaceted nature, so first task is to build a questionnaire that is quantifiable. The variables that are qualitative in nature can be quantifiable through likert scale.

The decision of the sample size is also necessary for getting best statistical analysis. So the sample size used is 250 questionnaire responses. However it can vary between 100 to 300 . The more the responses the more efficient statistical analysis will be. Collected data's be examined with no any stoppage for classifying or identifying corporate social responsibility. 


\subsection{Data entry}

After getting responses, that responses will be putted in SPSS. Of course, the software must track a arrangement that align with the questionnaires, i.e. contains same figure of column in the direction of counterpart no. of noticeable variable in favor of every model's dimension. Surveys methods have been functional toward determining corporate social responsibility. Also the questionnaire on behalf of that measurement is shown (Table 2). Respondent was invited toward assessing degree in the direction of which each of the factor is problematic for the growth and operation of CSR, with possible answers choice from 1 (zero social responsibility) to 5 (100\% social responsibility).

\section{ANALYSIS AND INTERPRETATIONS}

\subsection{Data Analysis}

Here approximation of the variety of parameter of CSR model's and computing index for all dimensions and also the concluding CSR indices will be discussed. Since every presentation feature is interconnected, index in favor of various variable in the model were determined at the same time consistent entire datasets. Throughout the outcomes given, corporation would be acquainted with how every measure impact taking place in the whole CSRI (path or structural coefficient) along with where development effort is additional probable toward having better impacts.

\subsection{Statistical reliablilty and validity of the model}

The methodology of CSRM (corporate social responsibility model) explains the construct, criterion and content validity for models. The inner's coefficient, reliability alphas, inner's $\mathrm{R}$ square along with indices of analysis tool be analyzed to facilitate and evaluate excellence of suitability moreover measurement of models.

\subsection{Inner Coefficient's}

The connection among the different CSR measurement and paths coefficient would be optimistic, highlighting principles along with nature of models. Those paths and inner coefficient is indication of relation among dependent along with independent variables of study. The value from Figure 2. as

well as Table 1. gives details so as to every coefficient are positive along with OSPS value is powerfully linked by means of further factor of models. 


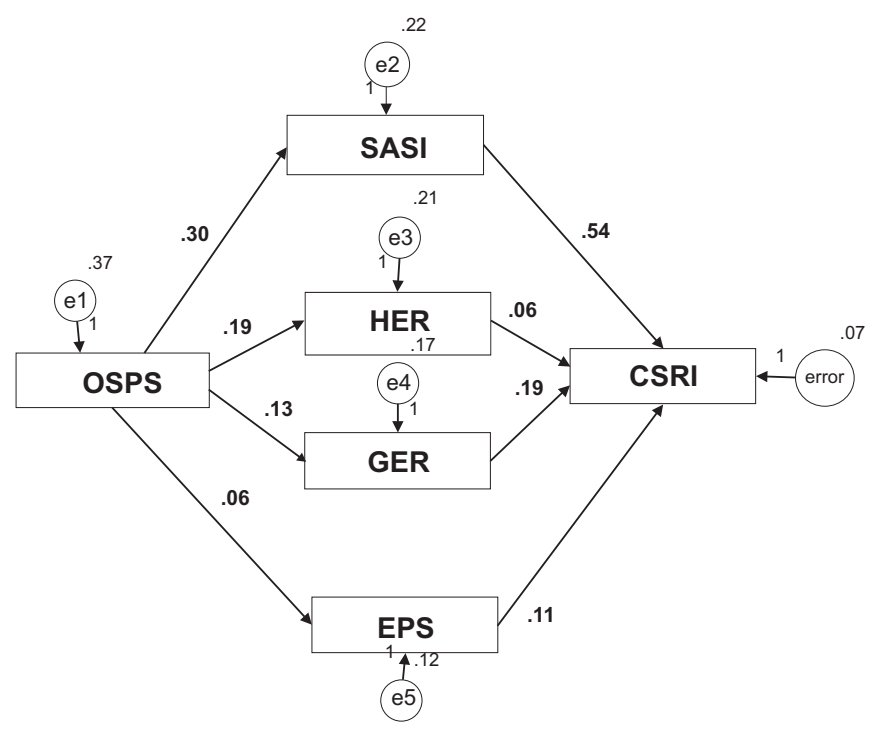

Figure 2: Path Coefficients of the model

Table 1: Inner coefficient of CSR model.

\begin{tabular}{|c|c|c|c|c|c|c|}
\hline & OSPS & SASI & HER & GER & EPS & CSRI \\
\hline OSPS & 0 & 0 & 0 & 0 & 0 & 0 \\
\hline SASI & 0.30 & 0 & 0 & 0 & 0 & 0 \\
\hline HER & 0.19 & 0 & 0 & 0 & 0 & 0 \\
\hline GER & 0.13 & 0 & 0 & 0 & 0 & 0 \\
\hline EPS & 0.06 & 0 & 0 & 0 & 0 & 0 \\
\hline CSRI & 0 & 0.54 & 0.06 & 0.19 & 0.11 & 0 \\
\hline
\end{tabular}

\subsection{Statistical reliability of the model}

The reliability alpha " $\alpha$ " scores for the model are shown in Table 2 . The reliability á scores of variable GER (Governance with economic responsibility) is below 0.70 , showing that variable is incompatible inside explanation of underlying variable and may be respondents was not able to understand questions.

Table 2: Alpha Values of the model.

\begin{tabular}{|l|c|c|c|c|c|}
\hline OSPS & SASI & HER & GER & EPS & CSRI \\
\hline 0.76 & 0.61 & 0.70 & 0.51 & 0.66 & 0.73 \\
\hline
\end{tabular}


The reliability $\alpha$ value of OSPS (0.76), SASI (0.61), HER (0.70), EPS (0.66) and CSR (0.73) was above or nearer to 0.70, Showing with the purpose of every underlying variable does model's fitness like optimistic pointer. Therefore, corporate social responsibility evaluating model's fitness is good. The powers of relationships are part of the RSS matching in the direction of dormant variable.

\subsection{Outer coefficient}

The outer coefficients explain how questions or query load in particular factor inside the CSR models. Tables 3. show how everyone variable participates in the direction of particular variables of corporate social responsibility model.

\subsection{The CSR indices}

That is comparatively simple toward deducing score got in favor of every one norm of CSR capacity scheme specified into Figure 3. and Table 4. The concluding CSR indexes would replicate concurrent result of every relationship expected inside models. Now the measuring tools consist of thirty eight questions in 6 elements so as to communicate toward 5 significant factors with CSR. Every question utilizes five points scales depending on that the organization are rated by respondents. The analysis of corporate social responsibility using the PLS (partial least squares) methods offered measures the power for cause-and-effect connections (Inner's coefficient) among model construct. The score of inner's coefficient is originated toward positives non-zero, giving hold to cause-and-effect association between significant variable as well as CSR.

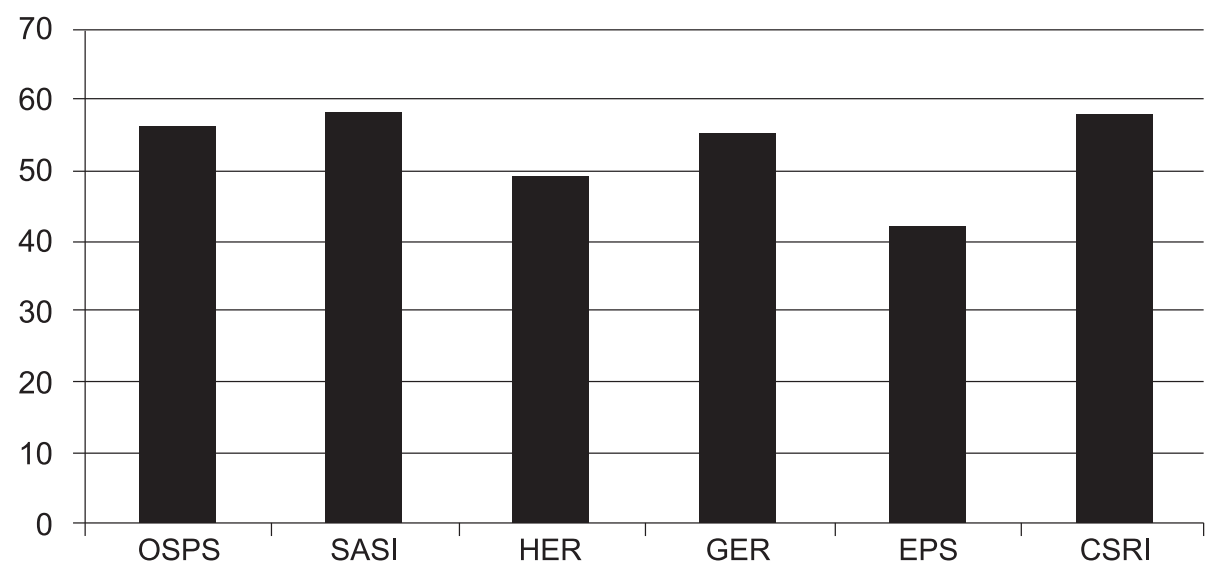

Figure 3: CSR Indices 
Table 3: Outer coefficients of the model.

\begin{tabular}{|c|c|c|c|c|c|}
\hline OSPS & SASI & HER & GER & EPS & CSR \\
\hline 0.240 & 0 & 0 & 0 & 0 & 0 \\
\hline 0.280 & 0 & 0 & 0 & 0 & 0 \\
\hline 0.209 & 0 & 0 & 0 & 0 & 0 \\
\hline 0.268 & 0 & 0 & 0 & 0 & 0 \\
\hline 0.291 & 0 & 0 & 0 & 0 & 0 \\
\hline 0.331 & 0 & 0 & 0 & 0 & 0 \\
\hline 0 & 0.172 & 0 & 0 & 0 & 0 \\
\hline 0 & 0.365 & 0 & 0 & 0 & 0 \\
\hline 0 & 0.247 & 0 & 0 & 0 & 0 \\
\hline 0 & 0.442 & 0 & 0 & 0 & 0 \\
\hline 0 & 0.258 & 0 & 0 & 0 & 0 \\
\hline 0 & 0.374 & 0 & 0 & 0 & 0 \\
\hline 0 & 0 & 0.333 & 0 & 0 & 0 \\
\hline 0 & 0 & 0.365 & 0 & 0 & 0 \\
\hline 0 & 0 & 0.214 & 0 & 0 & 0 \\
\hline 0 & 0 & 0.153 & 0 & 0 & 0 \\
\hline 0 & 0 & 0.237 & 0 & 0 & 0 \\
\hline 0 & 0 & 0.389 & 0 & 0 & 0 \\
\hline 0 & 0 & 0 & 0.380 & 0 & 0 \\
\hline 0 & 0 & 0 & 0.204 & 0 & 0 \\
\hline 0 & 0 & 0 & 0.417 & 0 & 0 \\
\hline 0 & 0 & 0 & 0.383 & 0 & 0 \\
\hline 0 & 0 & 0 & 0.419 & 0 & 0 \\
\hline 0 & 0 & 0 & 0.418 & 0 & 0 \\
\hline 0 & 0 & 0 & 0 & 0.314 & 0 \\
\hline 0 & 0 & 0 & 0 & 0.366 & 0 \\
\hline 0 & 0 & 0 & 0 & 0.335 & 0 \\
\hline 0 & 0 & 0 & 0 & 0.336 & 0 \\
\hline 0 & 0 & 0 & 0 & 0.395 & 0 \\
\hline 0 & 0 & 0 & 0 & 0.262 & 0 \\
\hline 0 & 0 & 0 & 0 & 0 & 0.280 \\
\hline 0 & 0 & 0 & 0 & 0 & 0.219 \\
\hline 0 & 0 & 0 & 0 & 0 & 0.267 \\
\hline 0 & 0 & 0 & 0 & 0 & 0.192 \\
\hline 0 & 0 & 0 & 0 & 0 & 0.284 \\
\hline 0 & 0 & 0 & 0 & 0 & 0.255 \\
\hline 0 & 0 & 0 & 0 & 0 & 0.149 \\
\hline 0 & 0 & 0 & 0 & 0 & 0.158 \\
\hline
\end{tabular}


Table 4: CSR Indices

\begin{tabular}{|c|c|c|}
\hline OSPS index & V1 & $56.33 \%$ \\
\hline SASI index & V2 & $58.49 \%$ \\
\hline HER index & V3 & $49.28 \%$ \\
\hline GER index & V4 & $55.11 \%$ \\
\hline EPS index & V5 & $42.38 \%$ \\
\hline CSR index & V6 & $58.04 \%$ \\
\hline
\end{tabular}

\subsection{Interpretations of results}

The response of the research's question that lead in the direction of outer coefficients (weights) as well as means score are examined to make possible for the interpretation of result. The research question provides insight in the direction of CSR by the interpretation with analysis for result. These grading system leads to the judgments. The lower the value of the index the lower will be CSR and vice versa. For example, if the value will be lower than 25\% then it will be indication of low CSR, while $50 \%$ will show middle level corporate social responsibility furthermore $75 \%$ will show high levels of corporate social responsibility. And exceeding 75\% will show higher levels of corporate social responsibility.

Table 5: Results of OSPS

\begin{tabular}{|l|l|c|c|}
\hline $\begin{array}{l}\text { Sr. } \\
\text { No. }\end{array}$ & Criteria & $\begin{array}{c}\text { Average } \\
\text { score }\end{array}$ & $\begin{array}{c}\text { Outer } \\
\text { coefficient }\end{array}$ \\
\hline 1. & $\begin{array}{l}\text { Classify, monitors, measures as well as } \\
\text { organize corporation's human resources } \\
\text { with ethical strategies }\end{array}$ & 3.265 & 0.240 \\
\hline 2. & $\begin{array}{l}\text { Estimate social aspects and socio economic } \\
\text { trend for company }\end{array}$ & 3.28 & 0.280 \\
\hline 3. & $\begin{array}{l}\text { Provides necessary stage for economic res- } \\
\text { ponsibility along with governance }\end{array}$ & 3.6 & 0.209 \\
\hline 4. & $\begin{array}{l}\text { Execute appropriate monitoring of internal } \\
\text { reporting system along with managing } \\
\text { communal investment with societal } \\
\text { accountability }\end{array}$ & 3.475 & 0.268 \\
\hline 5. & $\begin{array}{l}\text { Provide environment sustainability and } \\
\text { protection }\end{array}$ & 2.74 & 0.291 \\
\hline 6. & $\begin{array}{l}\text { Value the human rights of their employees } \\
\text { and common public at large }\end{array}$ & 3.28 & 0.331 \\
\hline
\end{tabular}


Using the CSRI formula (1) OSPS gives an index of 56.33\%, showing so as to the companies has middle levels of CSR (Table 4). The organizational strategic planning system result's reveals in Table 5 . The value of 0.331 in the illustrated study of outer coefficient shows that the matters of the general public and human right of employee is contributing a lot to the overall CSR index's as compared to others. The company is giving concentration along with significance to problem of human's right within the OSPS. Therefore planner have to improve more the condition of individual right in organization. The OSPS do not present necessary levels for economic responsibilities with governance as shown through coefficient's (0.209). Surroundings sustainability's along with protection like elements for OSPS are adding too small for general corporate social responsibility indexes. The companies rarely evaluate social aspects and socio economics trend for company, as shown through coefficient's (0.280). Also the outer coefficient of value 0.240 shows so as to the companies have not healthy procedures with system for identifying, monitoring, measuring along with controlling their human resources as well as ethical strategies. The company has a suitable internal reporting system to identify, monitor and control social investment and social accountability as shown through coefficient's (0.268).

Table 6: Results for SASI

\begin{tabular}{|l|l|c|c|}
\hline $\begin{array}{l}\text { Sr. } \\
\text { No. }\end{array}$ & Criteria & $\begin{array}{c}\text { Average } \\
\text { score }\end{array}$ & $\begin{array}{c}\text { Outer } \\
\text { coefficient }\end{array}$ \\
\hline 1. & $\begin{array}{l}\text { Business activities of the organization } \\
\text { are transparent and open }\end{array}$ & 3.965 & 0.172 \\
\hline 2. & $\begin{array}{l}\text { The company has a proper system for } \\
\text { prevention of corruption and financial } \\
\text { irresponsibilliy }\end{array}$ & 3.205 & 0.365 \\
\hline 3. & $\begin{array}{l}\text { Arrangement for creating a generally } \\
\text { encouraging impact in favor of the } \\
\text { betterment of humanity }\end{array}$ & 3.82 & 0.247 \\
\hline 4. & $\begin{array}{l}\text { The company is creating awareness among } \\
\text { people for health, education, food for } \\
\text { the betterment of society }\end{array}$ & 2.885 & 0.442 \\
\hline 5. & $\begin{array}{l}\text { The organization has made itself socially } \\
\text { accountable to meet public expectation }\end{array}$ & 3.685 & 0.258 \\
\hline 6. & $\begin{array}{l}\text { The public has complete awareness } \\
\text { regarding taking responsibility by the } \\
\text { organization of their services and products }\end{array}$ & 3.165 & 0.374 \\
\hline
\end{tabular}


The overall outcome for SASI is $58.49 \%$ shown in Table 4 is quite reasonable in that case. The detailed result of SASI (Social accountability and social investment) is shown in Table 6 . The outer coefficient of value 0.365 shows so as to there are sufficient structure in favor of stopping underhand dealings and fiscal unreliability. The openness along with transparency concerning its industry actions are too minute also participating extremely modest to the generally index's furthermore that ought to be alarming intended for SASI as shown through coefficient's (0.172).

Arrangement for creating a generally encouraging impact in favor of the betterment of humanity is unfortunate while shown through coefficient's (0.247). Conversely, the company has sufficient facilities for publicly responsible investment for healthcare, education, etc. shown through coefficient's (0.442). There are inadequate facilities for the organization to make it socially accountable to meet public expectation social accountability as shown through coefficient's (0.258).

Table 7: Results for HER

\begin{tabular}{|c|c|c|c|}
\hline $\begin{array}{l}\text { Sr. } \\
\text { No. }\end{array}$ & Criteria & $\begin{array}{l}\text { Average } \\
\text { score }\end{array}$ & $\begin{array}{c}\text { Outer } \\
\text { coefficient }\end{array}$ \\
\hline 1. & $\begin{array}{l}\text { For appropriate ethical decision, the } \\
\text { organization has properly trained its } \\
\text { employees }\end{array}$ & 3.49 & 0.333 \\
\hline 2. & $\begin{array}{l}\text { The organization is concerned about the } \\
\text { ecological as well as moral problems } \\
\text { for its consumer }\end{array}$ & 2.795 & 0.365 \\
\hline 3. & $\begin{array}{l}\text { The organization has implemented a } \\
\text { translucent structure in the direction of } \\
\text { analyzing the company's own labour } \\
\text { practices e.g. normal working hours, steps } \\
\text { against labour exploitation, harsh and } \\
\text { Inhumane workforce treatment and also } \\
\text { of entire supply chain }\end{array}$ & 3.85 & 0.214 \\
\hline 4. & $\begin{array}{l}\text { The organization has implemented a safe } \\
\text { and hygienic working environment for } \\
\text { its employee. }\end{array}$ & 4.035 & 0.153 \\
\hline 5. & $\begin{array}{l}\text { There is no discrimination in the } \\
\text { organization considering age, gender, } \\
\text { racial origins }\end{array}$ & 1.93 & 0.237 \\
\hline 6. & $\begin{array}{l}\text { The company keeps its employees in social } \\
\text { welfare activities like fundraising, payroll } \\
\text { giving and distribution of edible items }\end{array}$ & 2.415 & 0.389 \\
\hline
\end{tabular}


The index of HER is $49.28 \%$ that is under $50 \%$ telling with the intention of middle stage of actions, development plus resources within CSR except definite factor show so as to extra cautious interferences are mandatory regarding corporate social responsibility. Table 7. Discloses with the intention of present is be short of hygienic as well as safe functioning condition and in addition these of whole deliver sequence as shown through coefficient's (0.153). The company need well-built requirement in favor of company toward looking after that areas immediately. Conversely, the outer coefficient $(0.333)$ shows there is somehow a moral teaching within company for assisting workers to build suitable moral decision. The corporation should get better this area because this manifest variable contributed very small in the overall corporate social responsibility index. On the other hand, the companies have lack of amenities in favor of translucent structure in the direction of inspecting corporation labor practice like standard functioning hour, take steps alongside the misuse of labour, inhumane plus harsh conduct of labour force as well as whole delivery series while shown through coefficient's (0.214). Alternatively, the corporation engages its staff in actions like payroll giving, community volunteering or fundraising, since indicated through higher coefficient's (0.389).

Table 8: Results for GER

\begin{tabular}{|l|l|c|c|}
\hline $\begin{array}{l}\text { Sr. } \\
\text { No. }\end{array}$ & Criteria & $\begin{array}{c}\text { Average } \\
\text { score }\end{array}$ & $\begin{array}{c}\text { Outer } \\
\text { coefficient }\end{array}$ \\
\hline 1. & $\begin{array}{l}\text { The organization can change its policies by } \\
\text { taking pressure from the shareholders and } \\
\text { investors }\end{array}$ & 2.52 & 0.380 \\
\hline 2. & $\begin{array}{l}\text { To act socially responsibly the company } \\
\text { Interact with its stakeholders }\end{array}$ & 3.755 & 0.204 \\
\hline 3. & $\begin{array}{l}\text { Shareholders and stakeholders of the company } \\
\text { understand the reasons that are essential for } \\
\text { their employees as it creates business bene- } \\
\text { fits like more increased retention, higher } \\
\text { productivity, loyalty, etc. }\end{array}$ & 3.175 & 0.417 \\
\hline 4. & $\begin{array}{l}\text { The company does care of the life quality of } \\
\text { the employees and their families as well as } \\
\text { society overall. }\end{array}$ & 3.71 & 0.383 \\
\hline 5. & $\begin{array}{l}\text { The company is putting its contribution in } \\
\text { economic development of the country }\end{array}$ & 2.77 & 0.419 \\
\hline 6. & $\begin{array}{l}\text { The company arranges to create employment } \\
\text { opportunities for local communities }\end{array}$ & 3.56 & 0.418 \\
\hline
\end{tabular}


The overall score of GER index for corporations is $55.11 \%$, i.e. above $50 \%$ also needs cautious evaluations but is satisfactory. Coefficient's value 0.380 shows that the company can change their policy toward acting sensibly owing in the direction of pressures as of investors and shareholder are relatively up to the mark, taking their part in generally CSR's index. The outer coefficient for acting socially responsible the company Interact with its stakeholders (0.204) shows that the noticeable variables are too contributing minute toward common corporate social responsibility indexes. And therefore the need of hour is to get better in this area. There is medium level of participation in business through their shareholder as well as stakeholder of the company toward recognize reason which is essential for their employee because that creates industry benefit like increased retention, superior output and loyalty, because exposed through the coefficient's (0.417). Also company does care of the life quality of the employees and their families as well as society overall as shown through coefficient's (0.383). Also the corporations are putting its contribution in trade and industry growth (0.419). Therefore, that was obvious as of the analyses with the purpose of its different area which require interest and if these areas are properly addressed then GER can have more impact on overall CSR index.

Table 9: Results for EPS

\begin{tabular}{|l|l|c|c|}
\hline $\begin{array}{l}\text { Sr. } \\
\text { No. }\end{array}$ & Criteria & $\begin{array}{c}\text { Average } \\
\text { score }\end{array}$ & $\begin{array}{c}\text { Outer } \\
\text { coefficient }\end{array}$ \\
\hline 1. & $\begin{array}{l}\text { The company has proper \& concrete arrange- } \\
\text { ments to control environmental accidents } \\
\text { and mishaps }\end{array}$ & 3.19 & 0.314 \\
\hline 2. & $\begin{array}{l}\text { The company has publicized through electro- } \\
\text { nic and print media regarding ecological } \\
\text { effect of their product }\end{array}$ & 2.23 & 0.366 \\
\hline 3. & $\begin{array}{l}\text { The corporation considers the global environ- } \\
\text { mental considerations and re-brands its core } \\
\text { products accordingly }\end{array}$ & 2.515 & 0.335 \\
\hline 4. & $\begin{array}{l}\text { For global environmental problems the com- } \\
\text { pany has reduces its unwanted product } \\
\text { packaging }\end{array}$ & 3.13 & 0.336 \\
\hline 5. & $\begin{array}{l}\text { The company has self regulating mechanism } \\
\text { to supervise as well as make sure that its } \\
\text { observance to ecological protection }\end{array}$ & 2.84 & 0.395 \\
\hline 6. & $\begin{array}{l}\text { The company communicates with the parti- } \\
\text { cular group or society for the environmental } \\
\text { causes of its economic acts }\end{array}$ & 2.205 & 0.262 \\
\hline
\end{tabular}


The EPS index is 42.38 showing low accountability levels. The underneath table discloses so as to the value of outers' coefficients i.e. 0.314 shows that the company has below average arrangements to control environmental accidents and mishaps. The company has done enough publicized through electronic and print media regarding communal effect as shown through value of coefficient's 0.366 . Also 0.335 (coefficient's value) shows that corporation is considering at medium level for the global environmental considerations and re-brands its core products accordingly. The value 0.336 of outer coefficient shows that for global environmental problems the company has reduces its unwanted product packaging at medium level. Also, the company has self regu-

Table10. Results for CSR

\begin{tabular}{|c|c|c|c|}
\hline $\begin{array}{l}\text { Sr. } \\
\text { No. }\end{array}$ & Criteria & $\begin{array}{c}\text { Average } \\
\text { score }\end{array}$ & $\begin{array}{c}\text { Outer } \\
\text { coefficient }\end{array}$ \\
\hline 1. & $\begin{array}{l}\text { The company response in the direction of the } \\
\text { private organization in favor of their com- } \\
\text { munally conscientious behavior }\end{array}$ & 3.40 & 0.280 \\
\hline 2. & $\begin{array}{l}\text { The company uses the power of internet and } \\
\text { media to increase collective activism and } \\
\text { inspection about commercial behavior }\end{array}$ & 3.965 & 0.219 \\
\hline 3. & $\begin{array}{l}\text { Complete reward toward community on behalf } \\
\text { of poor environmental and social effect } \\
\text { of action }\end{array}$ & 3.015 & 0.267 \\
\hline 4. & $\begin{array}{l}\text { The company provides every means with tools } \\
\text { necessary for following wider communal goal } \\
\text { to its staff }\end{array}$ & 3.74 & 0.192 \\
\hline 5. & $\begin{array}{l}\text { The annual reports are external audited on } \\
\text { corporate social responsibility matters }\end{array}$ & 2.61 & 0.284 \\
\hline 6. & $\begin{array}{l}\text { The company opt the community-based } \\
\text { development projects like skills for adults, } \\
\text { children's education }\end{array}$ & 2.5 & 0.255 \\
\hline 7. & $\begin{array}{l}\text { Absolute obedience toward government's laws } \\
\text { avoiding them as of sourcing damage in the } \\
\text { direction of wider communal goods, involving } \\
\text { environment along with people }\end{array}$ & 4.335 & 0.149 \\
\hline 8. & $\begin{array}{l}\text { Company policies for corporate social respon- } \\
\text { sibility and in rank on how these policies are } \\
\text { put into practice and what outcomes have } \\
\text { been attained so far counting future expecta- } \\
\text { tions }\end{array}$ & 3.95 & 0.158 \\
\hline
\end{tabular}


lating mechanism to supervise as well as make sure that their observance for ecological protection (0.395). The coefficient's value 0.262 shows so as to corporations are not communicating well with the particular group or society for the environmental causes of its economic acts.

The CSR index is $58.04 \%$ that show modest stage of corporate communal liability. The noticeable variables of corporation reactions to non government organization designed for communally accountable actions do not appear toward issue a lot like shown through the lower values $(0.280)$. The Internet along with media has increased the collective activism as well as scrutiny about business behaviors have been contributing little also toward the overall corporate social responsibility index (0.219). The corporation policies for corporate social responsibility, how policies like that are put into practices as well as which type of result has attained up to now, as well as futures expectation too does not appear in the direction of matters a great deal (0.158). The coefficient's value i.e. 0.267 discloses so as to the companies do not appear toward providing complete reward for community on behalf of awful environmental and social effect of their products and actions. Also outer coefficient 0.192 indicates that the corporation does not appear to have a proper system to give its management and staff a mechanism to follow broader societal goals. The value 0.284 shows that the corporation annual reports are not properly external audited on corporate social responsibility matters. The company does not opt the community-based development projects like skills for adults, children's education, etc. as shown by the value 0.255 . The corporation also lacks of complete obedience to government's laws avoiding it on or after creating damage in the direction of the wider communal goods, together with environment along with people (0.149).

\section{Conclusions}

To summarize, at present corporations in Pakistan economy are increasing their promise to esteeming societal with ecological accountabilities, human rights, moral manage along with encouraging sustainability and enlargement during its product, process, service along with relationship. CSR as for Pakistan economy involves bring into line corporation's actions by means of environmental, monetary as well as social prospect for all those people who are influenced directly or indirectly by it. Though, CSR be capable of measuring from side to side the scale of CSR model. These measures are required for monitoring changes and benchmarking in excess of time that assist for creating change clear with make known CSR developments. The main variable that contributes in achieving moderate level of corporate social responsibili- 
ties was SASI because due to two main disasters (Earthquake in 2008 and Floods in recent two years) in Pakistan many of the firms have donated for the effected people and areas. So many firms have shown their donation in their annual reports and by media. Also many issues have arises during analysis, the question having a least value was about gender discrimination (1.93 out of 5) and highest score was about following Government regulation (4.34 out of 5). Now the need of hour is to improve the weaker one and sustain the stronger one in order to improve overall CSR in Pakistan economy.

That study gives orderly events, appropriate analysis of statistics along with advice plus improves an excellence by promising corporate communal accountability within Pakistan economy. Disagree through that, agree through that, dislike that, or like that, communal accountabilities are present, together by means of societal receptiveness, in addition to everybody have to exist among them. Society, company as well as government ought to effort jointly additional intimately for getting better creature answerability. Companies be ca-

pable of attaining together social responsiveness along with maximization of profits.

\section{References}

Bendell, I. (2005) 'In Whose Name? The Accountability of Corporate Social Responsibility', Development in Practice 15-3/4: 362-74.

Bhattacharya, C.B., Sen, S., \& Korschun, D. (2008). Using corporate social responsibility to win the war for talent. MIT Sloan Management Review, 49(2), 37-44.

Borelli, T.J. (2006, August 19). Club CSR [online article]. Retrieved from http://townhall.com/ columnists/TomBorelli/2006/08/19/club_csr?page1/4full\&comments 1/4true.

Bulkeley, H. (2001). Governing climate change: The politics and risk society? Transactions of the Institute of British Geographers, 26, 430-447.

Cronbach, L.J. (1951). Coefficient alpha and internal structure of tests. Psychometrika, 16, $297-334$.

Friedman, M. (1970, September 13). The social responsibility of business is to increase its profits. New York Times Magazine. Retrieved from http://www.colorado.edu/ studentgroups/libertarians/issues/friedman-soc-resp-business.html

Fry, L.W., Keim, G.D., \& Meiners, R.E. (1982). Corporate contributions: Altruistic or for profit? Academy of Management Journal, 25, 94-106.

Hussain Khaliq, S. (2004) 'Eliminating Child Labour from the Sialkot Soccer Ball', Journal of Corporate Citizenship 13 (Spring 2004):101-107. 
James, L.R., Mulaik, S.A., \& Brett, J.M. (1982). Causal analysis assumptions, models, and data. Beverly Hills: Sage.

Kanji, G.K. (2002). Measuring business excellence. London: Routledge.

Kanji, G.K., \& Chopra, P. (2007). Poverty as system: Human contestability approach to poverty measurement. Journal of Applied Statistics, 34, 1135-1158. 142 G.K. Kanji and P.K. Chopra.

Kanji, G.K., \& Chopra, P.K. (2009): Corporate social responsibility in a global economy, Total Quality Management Vol. 21, No. 2, February 2010, 119-143.

Kenny, D.A. (1979). Correlation and causality. New York: John Wiley.

Khan, F.S., and U. Noumani (2002) 'Corporate Social responsibility and Natural Disaster Reduction in Pakistan', Sustainable Development Policy Institute, www.sdgi.org, accessed 23 March 2006.

Kristina Praestbro Nielsen \& Rikke Winther Noergaard (2011): CSR and mainstream investing: a new match? - an analysis of the existing ESG integration methods in theory and practice and the way forward, Journal of Sustainable Finance \& Investment, 1: 3-4, 209-221.

Lund Thomson, P. (2004) 'Towards a Critical Framework on Corporate Social and Environmental Responsibility in the south: The Case of Pakistan', Development 47-3: 106-13.

Malik Asghar Naeem and Richard Welford. (2009): A Comparative Study of Corporate Social Responsibility in Bangladesh and Pakistan, Corporate Social Responsibility and Environmental Management, 16, 108-122.

McKibben, B. (2006, November/December). Hope vs hype. Mother Jones. Retrieved from http://www.motherjones.com/news/feature/2006/11/hype_vs_hope.html.

McMahon, S. (2005, October 17). BCA fights social responsibility law. The Age. Nunnally, J. (1967). Psychometric theory. New York: McGraw-Hill.

Orlitzky, M., Schmidt, F.L., \& Rynes, S.L. (2003). Corporate social and financial performance: A meta-analysis. Organization Studies, 24, 403-441.

Osorio, I. (2006). What exactly constitutes a corporation's 'social responsibility'? [online article]. Retrieved from http://www.eco-imperialism.com/content/article.php3?id1/4169.

PCP (Pakistan Center for Philanthropy) (2005) Corporate Philanthropy in Pakistan: The Case of Public Listed Companies (Islamabad, Pakistan: PCP). 
Richard Welford. (2007): Corporate Governance and Corporate Social Responsibility: Issues for Asia, Corporate Social Responsibility and Environmental Management, 14, 42-51.

Roux, M. (2007, September 4). Climate conducive to corporate action: 1 All-round country edition. The Australian. Retrieved from http://www.theaustralian.news.com.au/story/ 0,25197,22356183-7583,000.html

Rute Abreu, Fátima David, David Crowther, (2005),"Corporate social responsibility in Portugal: empirical evidence of corporate behaviour", Corporate Governance, Vol. 5 Iss: 5 pp. 3-18.

Sullivan, N., \& Schiafo, R. (2005, June 12). Talking green, acting dirty. New York Times.

Tobias Hahn and Mandy Scheermesser. (2006): Approaches to Corporate Sustainability among German Companies, Corporate Social Responsibility and Environmental Management, $13,150-165$.

Trapp, R. (2009, March 10). Corporate social responsibility is vital for business survival. The Independent. 